\title{
EWOLUCJA ZAGROŻENIA TERRORYSTYCZNEGO NA BLISKIM WSCHODZIE W 2016 ROKU
}

\section{ISTOTA I DETERMINANTY WSPÓLCZESNEGO ZAGROŻENIA TERRORYSTYCZNEGO}

Terroryzm jest zjawiskiem głęboko wpisującym się w historię i współczesność wielu państw regionu bliskowschodniego. Wielokrotnie próbowano w jednoznaczny sposób zdefiniować ten fenomen, jednakże dyskurs w tym zakresie jest daleki od zakończenia. Nie oznacza to jednak osiągnięcia względnego konsensusu w ramach społeczności akademickiej co do cech, które to zjawisko charakteryzują. Wśród nich wymienia się w szczególności: przemoc, użycie siły; polityczny charakter; strach; położenie nacisku na terror; groźba; skutki i antycypowane reakcje o psychologicznym charakterze; rozróżnienie ofiary i celu; celowa, planowana, systematyczna, zorganizowana akcja; metoda walki - strategia, taktyka; nienormalność, łamanie powszechnie akceptowanych reguł; brak humanitarnych ograniczeń; przymuszanie, wymuszanie, powodowanie uległości; aspekt rozgłosu (publicity); arbitralność; bezosobowość; cywile, niewalczący, neutralni, osoby postronne jako ofiary; zastraszanie, podkreślenie niewinności ofiar; grupa, ruch, organizacja, jako sprawca; aspekt symboliczny; demonstracja wobec innych; nieobliczalność, nieprzewidywalność, niespodziewane pojawienie się aktu przemocy; utajniona, skryta natura; powtarzalność, seryjny lub kampanijny charakter przemocy; kryminalny charakter aktywności, żądania stawiane stronom trzecim (Schmid, Jongman, 2005: 5-6; Weinberg, Pedahzur, Hirsch-Hoefler, 2004: 781). Panuje także względna zgoda odnośnie tego czym terroryzm z pewnością nie jest (choć niektórzy badacze czy publicyści zdają się tej części ustaleń w ogóle nie zauważać). A. P. Schmid twierdzi na przykład, iż terroryzmem nie są akty przemocy polegające na: niszczeniu cudzej własności (w tym przypadku należy jednak założyć, że motywy polityczne takich działań mogą sugerować akt terrorystyczny), atakowaniu infrastruktury wojskowej (okrętów wojennych, samolotów wojskowych, zabudowań, z których korzysta wojsko), atakowaniu policjantów i infrastruktury wykorzystywanej przez policję w czasie konfliktów zbrojnych (nawet jeśli przypadkowymi ofiarami takich działań są cywile), atakowaniu świeckich lub religijnych symboli, chyba, że celem takiego ataku są także cywile (atak na sam budynek kościoła, synagogi czy meczetu bez jakichkolwiek ofiar nie jest zatem aktem terrorystycznym), dokonywaniu bezpośrednich zabójstw (kiedy ofiara jest tylko konkretna osoba) w przeciwieństwie do sytuacji, w których ginie więcej osób, a to masowe zabójstwo to generuje uwagę jakiegoś szerszego audytorium, użyciu siły w czasie konfliktów zbrojnych, które nie kwalifikują się jako przestępstwa wojenne, przestępstwa przeciwko ludzkości lub 
naruszenie prawa konfliktów zbrojnych, aktywności partyzanckiej, która nie kwalifikuje się jako przestępstwa wojenne, przestępstwa przeciwko ludzkości lub naruszenie prawa konfliktów zbrojnych, zgodnym z prawem użyciem przemocy przez legalnie wybrane władze mające na celu zaprowadzenie porządku społecznego, adekwatne do istniejącego zagrożenia, podjętym w granicach obowiązującego prawa; użyciu przemocy w celach politycznych, jeśli są to akty spontaniczne, takie jak np. demonstracje i inne formy publicznego protestu (np. rewolucje) (Schmid, 2011: 84).

W klasycznym dyskursie na temat przyczyn rozwoju zjawiska terroryzmu pojawia się kwartet powiązanych ze sobą wzajemnie elementów. Są to przyczyny historyczno-polityczne (Byman, 2007: 10-14; Madej, 2001: 53-57), kulturowo-religijne (Roy, 2006: 167; Jurgensmeyer, 2006: 142), społeczno-ekonomiczne (Ehrlich, Liu, 2002: 183-192; Gurr, 2006: 86) i techniczno-technologiczne (Adamski, 2007: 7-8). W przypadku analizy źródeł terroryzmu bliskowschodniego powyższą typologię uznać należy za przydatną pamiętając jednak o kluczowym miejscu dwóch pierwszych grup powodów. Polityczno-historyczne źródła terroryzmu na Bliskim Wschodzie ściśle łączą się zarówno z nacjonalizmem (dychotomiczne ujęcie tej ideologicznej perspektywy tłumaczy po części istotę sporu żydowsko-palestyńskiego), jak i imperializmem (dominacja i angażowanie się państw hegemonicznych w sprawy regionu wpływało dysfunkcjonalnie na sytuację społeczną, ekonomiczną i polityczną jego mieszkańców) (Sinclair, 2003: 271-282). Społeczne źródła terroryzmu bliskowschodniego ściśle wiążą się natomiast $\mathrm{z}$ mobilizacją grup społecznych zaangażowanych $\mathrm{w}$ realizację celów politycznych przy użyciu niestandardowych metod (np. przemocy ze szczególnym uwzględnieniem taktyki zamachów samobójczych) (Kitschelt, 2004: 164-168). Herbert Kitschelt uzupełnił te wskazania o czynnik ekonomiczny, uznając ekonomiczną deprywację i marginalizację społeczną dużej części społeczeństw zamieszkujących region Bliskiego Wschodu za ważną przesłankę narodzin terroryzmu etniczno-religijnego (Kitschelt, 2004: 179-181). Kluczową rolę w rozwoju ostatniej fali rozwoju terroryzmu na analizowanym obszarze odegrał jednak czynnik kulturowo-religijny. Islamski i żydowski fundamentalizm w zauważalny sposób odcisnęły swoje piętno na ewolucji terroryzmu religijnego, doprowadzając do narodzin wielu mniej lub bardziej znanych grup terrorystycznych (Krawczyk, 2007: 59-68, 80-108).

\section{PRZEGLĄD AKTYWNYCH PODMIOTÓW TERRORYSTYCZNYCH NA BLISKIM WSCHODZIE}

Bliski Wschód jest bez wątpienia obszarem, gdzie obserwować można dynamiczny i wielowątkowy rozwój analizowanego fenomenu. Na przestrzeni ostatnich kilkudziesięciu lat powstało co najmniej kilkanaście znaczących grup terrorystycznych o różnej proweniencji ideologicznej, walczących dość często o różne (także rozbieżne) cele, współegzystujących ze sobą lub, co częstsze, zwalczających się nawzajem. Były to zarówno organizacje odwołujące się do świeckich, w tym nacjonalistycznych haseł, jak też i grupy silnie akcentujące hasła religijne. W tym pierwszym przypadku wskazać można choćby na terroryzm kurdyjski, którego najważniejszą emanacją była aktywność Partii Pracujacych Kurdystanu (PPK) czy też związa- 
nych z tą grupą bojówek, działających przede wszystkim na obszarze Syrii w postaci Jednostek Obrony Ludu (YPG) oraz rozłamowych Sokołów Wolności Kurdystanu (SWK), w tym drugim zaś organizacje dżihadystyczne w postaci Państwa Islamskiego (PI) czy Al-Kaidy (AK) i związanych z nią regionalnych siatek terrorystycznych np. Frontu an-Nusra (FN, który po zerwaniu związków z Centralnym Dowództwem Al-Kaidy zmienił - na początku 2017 r. - nazwę na Hajat Tahrir as-Szam (HTS) czy Al-Kaidy na Półwyspie Arabskim (AKPA). Analiza aktywności terrorystycznej w regionie w 2016 r. prowadzi do konstatacji, iż marginalną aktywność wykazywały organizacje palestyńskie (w postaci Hamasu czy Hezbollahu). Zasadne jest też podkreślenie coraz większego znaczenia taktyki terroryzmu indywidualnego, która wykorzystywana była przede wszystkim przez Palestyńczyków na obszarze Izraela i Autonomii Palestyńskiej.

\section{CHRONOLOGIA AKTYWNOŚCI TERRORYSTYCZNEJ NA BLISKIM WSCHODZIE W ROKU 2016}

W wielu dostępnych analizach (bardziej o publicystycznym niż naukowym charakterze) aktywności terrorystycznej wykorzystywane jest rozszerzające ujęcie istoty aktywności terrorystycznej. Za akty terrorystyczne uznaje się np. wszystkie akty wykorzystujące klasyczną taktykę terrorystyczną (np. eksplozje ładunków wybuchowych czy zamachy samobójcze), bez względu na cel ataku (np. atakowanie policjantów czy żołnierzy) i motywy, którymi kierowali się sprawcy (inne niż polityczne). W wielu przypadkach, z uwagi na zwłokę lub brak reakcji ze strony organizacji terrorystycznej, która przyznałaby się do przeprowadzenia zamachu trudno jest ad hoc zapisać daną akcję terrorystyczną na konto konkretnych podmiotów terrorystycznych. Stąd też wprowadzać w błąd mogą powszechnie dostępne statystyki powyższej aktywności wliczające do ogólnej liczby aktów terrorystycznych także akcje mające charakter partyzancki. Co więcej, część funkcjonujących w obiegu publicznym danych może i powinna być w związku z tym krytycznie zweryfikowana.

Abstrahując jednak od wskazanych problemów metodologicznych zauważyć należy, iż w analizowanym okresie obserwować można było utrzymywanie się zagrożenia terrorystycznego na Bliskim Wschodzie na stałym, wysokim poziomie. Najpoważniejsze wyzwanie z nim związane pochodziło ze strony dwóch struktur: Państwa Islamskiego i Al-Kaidy na Pótwyspie Arabskim. Geografia zagrożenia terrorystycznego obejmowała swym zasięgiem większą część Półwyspu Arabskiego (właściwie poza Zjednoczonymi Emiratami Arabskimi czy Omanem). Jego natężenie było zaś ściśle skorelowane z zasięgiem aktywności konkretnych grup terrorystycznych.

Państwo Islamskie skorelowało swoją aktywność z relatywnymi sukcesami społeczności międzynarodowej mającymi na celu ograniczenie jego aktywności i ostateczne rozbicie. Innymi słowy wraz z utratą kolejnych obszarów kontrolowanych przez tę protopaństwową strukturę (Wejkszner, 2016: 41-45) rosła aktywność terrorystyczna skierowana wobec Irakijczyków i Syryjczyków popierających reżimy walczące z Państwem Islamskim (sporadyczne akcje terrorystyczne przypisywane tej strukturze podejmowane były także na Zachodzie). 
Państwo Islamskie kontynuowało swą takfirystyczną strategię atakowania szyitów (Wejkszner, 2016: 82-83). Jej emanacją były choćby zamachy w al-Hilli (3 stycznia) (Bomb, 2016), Bagdadzie (25 lutego) (Two, 2016), 30 kwietnia (At, 2016a), 3 lipca (Almukhtar, Watkins, 2016), 25 września (Suicide bomber targets, 2016), 27 września (Blasts, 2016) czy 3 października (At, 2016c), Mukdadiji (29 lutego) (IS Claims Killing 60, 2016), Samawie (1 maja) (Iraq, 2016), Ain al-Tamr (28 sierpnia) (Islamic, 2016) czy też atak na szyickie mauzoleum w Balad (7 lipca) (SITE, 2016d) w Iraku, atak w saudyjskim Mahasen (29 stycznia) (Hanna, Basil, Noam, 2016), syryjskim Damaszku (21 lutego) (Damascus, 2016) czy też zamach na przywódcę szyickiej rebelii w jemeńskiej Sanie (22 lipca) (al-Qalisi, 2016). Większość z powyższych zamachów miało postać zamachów samobójczych. Zabito w nich łącznie kilkaset osób. Z taktycznego punktu widzenia celem tych ataków miało być nie tylko zastraszenie społeczności szyickiej, ale także wzniecenie konfliktu polityczno-religijnego pomiędzy szyitami a sunnitami. Taktyka ta okazała się jednak wybitnie nieskuteczna.

Terroryści z Państwa Islamskiego z pełną premedytacją atakowali tzw. miękkie cele w Syrii i Iraku, prowadząc mało efektywną kampanię terroru. 11 stycznia 2016 r. zaatakowali cywilów w Bagdadzie (Rowley, 2016), Bakubie (Dozens, 2016) i al-Mikdadiji (ibid.), zabijając dziesiątki cywilów. 31 stycznia w miejscowości Set Zaynab w pobliżu Damaszku w Syrii miał miejsce symultaniczny atak samobójczy, w wyniku którego śmierć poniosło co najmniej 60 osób (Three, 2016). Kolejne serie zamachów bombowych na terytorium Syrii miała miejsce w 21 lutego (wtedy zaatakowano cywilne cele w Homs i Damaszku. W zamach tych zginęło łącznie ponad 140 osób, a setki kolejnych zostało rannych (Damascus, 2016), 23 maja (celem ataku terrorystów-samobójców były wówczas cele cywilne w Tartusie i Dżabli (Davision, 2016). Wielokrotnie symultaniczne ataki terrorystyczne przeprowadzane były w stolicy Iraku, np. 2 lutego (Six, 2016a), 4 kwietnia (IS Claims Killing Over, 2016), 8 maja (Multiple, 2016) i poza nią (m.in. 7 czerwca, kiedy to zaatakowano cele w takich miejscowościach, jak Karbala czy al-Hadisa (Adnan, 2016)). Atakowano też cele kurdyjskie. 18 czerwca przeprowadzono samobójczy zamach bombowy w pobliżu siedziby Patriotycznej Unii Kurdystanu w Tuz Churmatu, w wyniku którego śmierć poniosły przynajmniej 4 osoby (Car bomb kills, 2016).

O wykorzystywaniu przez Państwo Islamskie osób niepełnoletnich do przeprowadzania zamachów samobójczych świadczy choćby akcja z 25 marca, kiedy to zaatakowano cywilów na meczu piłkarskim w irackiej Iskandariji, zabijając co najmniej 65 osób (IS Claims Killing, Wounding, 2016) oraz zamach z 20 sierpnia w tureckim Gaziantep, kiedy to ok. 12 letni zamachowiec-samobójca zaatakował uczestników ceremonii ślubnej (Yeginsu, 2016a). Kolejnym świadectwem tego stanu rzeczy był samobójczy zamach bombowy w irackim Churmatu 3 września przeprowadzony przez nastolatka (Dolamari, 2016). Z pełną świadomością wybierano także symboliczne cele ataku, piętnując tym samym zachowania nieprzystające do promowanej przez Państwo Islamskie wizji stosunków społecznych. Emanacją takiej taktyki był choćby atak na kibiców Realu Madryt oglądających mecz piłkarski w jednej z restauracji w irackiej Bakubie 28 maja (Couzens, 2016). Atakowano także cele infrastrukturalne, czego przykładem był choćby atak na elektrownię w Tadżi w pobliżu Bagdadu 15 maja (Hume, Alkhashali, 2016) czy też atak na energetyczną infrastrukturę przesyłową w pobliżu Tikritu 22 czerwca (ISIS, 2016). Anegdotyczny, ale świadczący o niewydolności 
i korupcji irackich struktur państwowych, wydaje się być skandal mający związek z detektorami ładunków wybuchowych, które policja iracka używała do wykrywania przygotowywanych zamachów bombowych. Brak sukcesów w tym względzie mógł być związany z faktem, że producent tych urządzeń okazał się być oszustem. Zaś jego „wynalazek” był niczym więcej, jak tylko urządzeniem służącym wykrywaniu zagubionych piłek golfowych. Na zakup tych urządzeń od firmy brytyjskiej iracki rząd wydał ok. 40 mln USD (Hameed, Chimaytelli, 2016).

Atakowano również cele na Bliskim Wschodzie leżące poza terytorium kalifatu. 12 stycznia Saudyjczyk Nabil al-Fadli przeprowadził spektakularny zamach samobójczy w Stambule, w Turcji. Celem zamachu w dzielnicy Sultanhamet, w pobliżu Obelisku Teodozjusza, byli zagraniczni turyści. W jego wyniku śmierć poniosło 10 osób (w tym 8 turystów z Niemiec) (Serbest, 2016). Wybór miejsca (popularnego wśród turystów) i zadbanie o to, aby wśród ofiar nie było muzułmanów (lub było ich jak najmniej) miały być, w opinii Nihata Ali Ozcana, świadectwem zmiany taktyki Państwa Islamskiego (Ozcan, 2016: 8). Nic jednak bardziej mylnego. To po prostu emanacja konfliktu z tzw. wrogiem dalekim na obszarze kontrolowanym przez tzw. wroga bliskiego (Wejkszner, 2016: 86-87). Kolejny zamach przypisywany Państwu Islamskiemu miał miejsce w tym samym mieście 19 marca. Zamachowiec-samobójca zabił wówczas w centrum Stambułu co najmniej 5 osób. Wśród rannych byli zaś obywatele Izraela (Zeyerk, 2016). Symultaniczną samobójczą akcję terrorystyczną przeprowadzono także w libańskiej wiosce Qaa 27 czerwca. Jej celem byli chrześcijanie (Eight, 2016). Dzień później trzech terrorystów PI pochodzących z obszaru byłego ZSRR zaatakowało cywilów na lotnisku w Stambule, zabijając co najmniej 44 osoby, a raniąc ponad 200 (Yegnisu, Callimachi, 2016).

Działania podejmowane przez Państwo Islamskie w 2016 r., włącznie z aktami terroryzmu, nie zatrzymały trendu obserwowanego już od końca 2015 r., związanego z kurczeniem się obszaru kontrolowanego przez tę grupę oraz zmniejszenia się efektywności działań propagandowo-rekrutacyjnych. Powodem tego stanu rzeczy był od samego początku brak geopolitycznej głębi projektu odbudowy kalifatu opartego jedynie na hiperradykalizmie dżihadystów i braku społecznego poparcia wśród społeczności muzułmańskiej. Przemoc terrorystyczna, masowe morderstwa i kryminalizacja aktywności dżihadystów z Państwa Islamskiego doprowadziła do konieczności toczenia wojny przez bojowników tego protopaństwa na trzech głównych frontach: na północy z Kurdami, na zachodzie z poplecznikami reżimu al-Assada i na wschodzie z Irakijczykami. Poza tym bojownicy z Państwa Islamskiego znaleźli się pod stałą presją międzynarodowej koalicji antyterrorystycznej na czele z USA oraz wspierającej reżim al-Assada Rosji (Shapiro, 2016: 28).

Al-Kaida na Pótwyspie Arabskim, lokalna sieć komórek, będąca przynajmniej od 2009 r. częścią globalnej sieci Al-Kaidy (Wejkszner, 2017: 146-148), aktywna była w szczególności na obszarze Jemenu, gdzie konkurować musiała przede wszystkim z Państwem Islamskim. Al-Kaida na Pótwyspie Arabskim, podobnie jak inne organizacje afiliowane i regionalne sieci komórek operacyjnych, próbowała w 2016 r. wdrożyć w życie strategię bardziej umiarkowanej aktywności, stroniąc od atakowania ludności cywilnej (co zauważalne jest w podczas porównania aktywności AKPA i Państwa Islamskiego) $\mathrm{i}$ hiperradykalizmu. W zamian, mając na uwadze strategiczny plan budowy 
struktur państwa islamskiego próbowano zjednać sobie lokalną społeczność realizując trójelementowy plan działania polegający na: dostarczaniu lokalnej społeczności podstawowych usług publicznych na kontrolowanych przez siebie obszarach, wchodząc $\mathrm{w}$ dobre relacje $\mathrm{z}$ lokalnymi strukturami plemiennymi oraz nawiązując współpracę z lokalnymi grupami toczącymi walkę z rebeliantami Huti (Horton, 2017: 17). Jednakże już w pierwszej połowie 2016 r. AKPA znalazło się w odwrocie wycofując się pod naciskiem sił saudyjskich z al-Mukalla. Odwrót był jednak w pełni kontrolowany i obejmował nie tylko sprzęt wojskowy, ale także środki finansowe (w wysokości ok. $100 \mathrm{mln}$ USD) przejęte w lokalnym oddziale banku (Horton, 2016: 8).

Walka o wpływy pomiędzy dżihadystami w tej części półwyspu uzewnętrzniała się także poprzez aktywność terrorystyczną. Jej emanacją był szereg akcji podejmowanych przez obie organizacje. Jedną z nich był zamach na gubernatora Adenu z 5 stycznia (Yemen, 2016). 5 maja w miejscowości Marib w Jemenie celem zamachu był lokalny rynek, na którym handlowano narkotykiem kat (catha edulis). Dżihadyści z AKPA zakazali jego spożywania. Atak miał skłonić lokalną społeczność do podporząqkowania się temu zakazowi (Six Dead, 2016). Wielokrotnie, w ramach asymetrycznych działań skierowanych przeciwko reżimowi jemeńskiemu podejmowano akcje o charakterze partyzanckim, wykorzystując choćby taktykę zamachów samobójczych. Przykładem takich działań AKPA (mających w istocie także odwetowy charakter) był w szczególności samobójczy atak na policyjne centrum rekrutacyjne w miejscowości al-Mukalla w Jemenie 15 maja, w którym zginęło ok. 40 osób (Suicide Bomber Targets, 2016).

$\mathrm{O}$ wiele mniejszą aktywność terrorystyczną przypisać należy innym regionalnie działającym grupom, w tym PKK/YPG oraz Frontowi an-Nusra. Wydaje się, iż powyższe organizacje były bardziej zaangażowane w aktywność partyzancką, niż terrorystyczna.

Partia Pracujacych Kurdystanu i związane z nią Jednostki Obrony Ludu (YPG), miały być odpowiedzialne, zdaniem władz tureckich, za szereg zamachów terrorystycznych na terytorium tego państwa. Jednym z przykładów takiej aktywności był zamach samobójczy przeprowadzony 13 marca w Stambule, kiedy to terrorysta zdetonował ładunek wybuchowy umieszczony w samochodzie w pobliżu przejeżdżającego autobusu miejskiego, zabijając co najmniej 32 osoby (Coskun, 2016). Choć organizacja PPK nie przyznała się do tego zamachu, to władze tureckie wykorzystując powyższy pretekst przeprowadzily wnet ataki odwetowe (m.in. na terytorium Syrii). Podobnie stało się w przypadku samobójczego zamachu w Tunceli z 13 czerwca, w którym zdetonowano ładunek wybuchowy tuż obok budynku mieszkalnego znajdującego się w pobliżu lokalnego sądu (Car bomb hits, 2016). Wiele rzekomych zamachów przypisywanych PPK przez władze miało w istocie postać partyzantki miejskiej, gdyż celami tychże ataków były służby mundurowe (zwłaszcza policyjne). Jednym z przykładów takich ataków był choćby zamach w Diyarbakir przeprowadzony 10 sierpnia (At least 9, 2016). Atakowano posterunki oraz lokalne siedziby policji, jak też i pojazdy policyjne. PPK obarczono także atakami na opozycyjnych polityków. Emanacją takiej aktywności był zamach na Kemala Kılıçdaroğlu, przewodniczącego Republikańskiej Partii Ludowej (głównej tureckiej partii opozycyjnej), przeprowadzony 25 sierpnia $2016 \mathrm{r}$. w pobliżu miejscowości Artvin w Turcji (Turkish, 2016). 
Warto podkreślić, iż aktywność terrorystyczną kontynuowały także komórki operacyjne Sokołów Wolności Kurdystanu - rozłamowej grupy, która odłączyła się ponad dekadę temu od PKK. Przykładami akcji powyższej grupy były zamachy z 13 marca w Ankarze, w którym zginęło 37 cywilów (Yeginsu, 2016b) oraz z 7 czerwca (Istanbul bombing, 2016) i 10 grudnia w Stambule (Istanbul terror, 2016).

Front an-Nusra od początku 2016 r. kontynuował działania paramilitarne skierowane przeciwko reżimowi al-Assada. Sporadycznie podejmował także akcje terrorystyczne. Jedną z nich było porwanie dwóch rebelianckich opozycjonistów w Kafr Nabl 10 stycznia 2016 r. krytykujących poczynania Frontu (Al-Qaeda's, 2016).

28 lipca 2016 r. Front an-Nusra (a właściwie Dżabhat an-Nusra li Ahl as-Szam - Front Wsparcia Ludu Syryjskiego) zmienił swoją nazwę na Dżabhat Fatah as-Szam (Front Wyzwolenia Syrii), rezygnując oficjalnie z afiliacji przy Centralnym Dowództwie Al-Kaidy. Ten radykalny zwrot zaakceptowany został wcześniej przez przywódcę Al-Kaidy Ajmana az-Zawahiriego i motywowany był chęcią unifikacji pod sztandarem organizacji wielu pomniejszych grup islamistycznych. Nie zmieniły się jednakże cele strategiczne grupy, wśród których najważniejszym w dalszym ciągu było utworzenie na terytorium Syrii emiratu, którego powstanie miało być częścią śmielszego planu odbudowy kalifatu (al-Tamimi, 2016: 16-19). Ważnym skutkiem powyższego posunięcia (m.in. w związku z kontynuowaniem taktyki walki partyzanckiej z reżimem alAssada) był wzrost popularności powyższej grupy wśród społeczności muzułmańskiej w Syrii (Lister, 2016: 17). Pozwoliło ono także zróżnicować wizerunek nowej grupy w odniesieniu do Państwa Islamskiego (choć nie zapobiegło to dezercji części najradykalniejszych członków Frontu i przyłączenia się do tej ostatniej grupy (Pothecary, 2016: 7)) i w jakieś mierze zdelegitymizować pozostałą antyassadowską opozycję.

Osobną kwestią były zaś pojedyncze ataki terrorystyczne na obszarze Izraela i Autonomii Palestyńskiej, którego głównymi sprawcami byli terroryści palestyńscy bez konkretnej afiliacji (tzw. samotne wilki czy też terroryści indywidualni) lub związani z którąs z lokalnie działających grup terrorystycznych. Co najmniej dwa tego typu zamachy miały miejsce w styczniu 2016 r. - w Tel Awiwie (Izrael) i w Hebronie (Autonomia Palestyńska). 1 stycznia Naszat Melhem, 31-letni Palestyńczyk posiadający izraelskie obywatelstwo ostrzelał żydowską kafejkę zabijając 2 osoby i raniąc 7 kolejnych. Izraelska policja zabiła go tydzień później podczas próby zatrzymania (Benari, 2016). Po jego śmierci na portalach społecznościowych wielu zwolenników Hamasu apoteozowało jego poświęcenie dla sprawy palestyńskiej. W kolejnych tygodniach dość często dochodziło także do ataków nożowników (m.in. w dniu 3 stycznia w Jerozolimie (Man, 2016), 17 stycznia w miejscowości Otniel w pobliżu Hebronu (Zitun, 2016), 18 stycznia w Tekoa (Palestinan, 2016), 25 stycznia w Beit Horon (Wootliff, 2016), 3 lutego w pobliżu Bramy Demasceńskiej w Jerozolimie (Gross, 2016), 14 lutego w pobliżu Groty Makpela w Hebronie (Baruch, 2016), 30 czerwca w miejscowości Kiryat Arba (Ben-Kimon, Levy, 2016). 11 sierpnia w Beit Hoshen kolejny palestyński terrorysta zaatakował obywatela Izraela przy użyciu śrubokręta (Hasson, 2016). Terroryści palestyńscy atakowali także obywateli innych państw, czego przykładem może być choćby zasztyletowanie 8 marca w Tel Awiwie amerykańskiego studenta (Schram, Steinbuch, 2016). 8 czerwca dwóch Palestyńczyków zaatakowało Żydów w jednej $\mathrm{z}$ restauracji $\mathrm{w}$ Tel Awiwie. Policja nie potwierdziła, co prawda ich afiliacji terrory- 
stycznej, ale zaraz po zamachu został on pozytywnie przyjęty przez przedstawicieli Hamasu (Kubovich, 2016). Część $\mathrm{z}$ ataków palestyńskich nożowników nie może być jednak uznana za akty terrorystyczne, gdyż ich celem były służby mundurowe, a motywacja znakomitej części sprawców nie została nigdy ujawniona.

Aktywność terrorystyczna w tej części świata w 2016 r. ograniczona co prawda do kilku państw regionu (głównie Syrii, Iraku, Jemenu i Turcji) miała jednakże dysfunkcjonalny wpływ na poziom bezpieczeństwa na całym Bliskim Wschodzie. Proliferacja niestabilności, połączona z asymetryczną aktywnością wspomnianych wyżej grup terrorystycznych, była bardzo poważnym wyzwaniem nie tylko dla lokalnych podmiotów państwowych, ale także całej społeczności międzynarodowej. Jego emanacją było bezpośrednie zaangażowanie państw spoza regionu (z obszaru wspólnoty euroatlantyckiej i Rosji) w nieudane próby przywrócenia ładu pokojowego. Ta aktywność, paradoksalnie, prowokowała dalszy sprzeciw islamskich radykałów, nakręcając spiralę przemocy w regionie.

\section{PREDYKCJA AKTYWNOŚCI TERRORYSTYCZNEJ NA BLISKIM WSCHODZIE}

Analiza dynamiki aktywności terrorystycznej w odniesieniu dla analizowanego obszaru pozwala na zarysowanie kilku mniej lub bardziej wyraźnych trendów, które utrzymać się mogą zarówno w roku 2017, jak też i późniejszym czasie.

Warto zauważyć, przede wszystkim, iż bliskowschodni terroryzm jest emanacją trwającej na wielu polach walki politycznej, której ofiarami staje się ludność cywilna. $Z$ jednej strony znacząca część aktów terroryzmu na tym obszarze jest efektem wprowadzania w życie islamistycznej wizji odbudowy kalifatu, z drugiej zaś świadectwem bezsilności w trwającym od dziesięcioleci konflikcie narodowowyzwoleńczym toczonym przez Palestyńczyków. Powyższe zamierzenia nie doczekały się, jak dotąd realizacji (trudno uznać za sukces chwiejące się u podstaw dżihadystyczne protopaństwo nazywane Państwem Islamskim). Terroryzm jest w tym przypadku jedynie narzędziem służącym do wywarcia presji na wrogiej społeczności i mobilizacji muzułmanów wokół strategicznych celów walki asymetrycznej.

Znakomita większość grup terrorystycznych działających na Bliskim Wschodzie aktywna jest od co najmniej kilku lat. Ekstrapolacja ich aktywności w najbliższej przyszłości zakłada, iż jej poziom, choć może ulegać niewielkim fluktuacjom, raczej się nie zmieni. Można założyć, z pewną dozą prawdopodobieństwa, upadek terytorialnych struktur Państwa Islamskiego już w 2017 r. (choć zapewne stanie się to nieco później) (Shapiro, 2016: 28-31). Nic jednak nie wskazuje na to, iż dżihadyści walczący pod jego sztandarem zrezygnują z walki z niewiernymi po utracie kontroli nad znakomitą częścią Syrii i Iraku. Państwo Islamskie zamiast tworem protopaństwowym będzie znów tylko sieciową strukturą terrorystyczną walczącą o powrót do realizacji zamierzeń strategicznych. W tej perspektywie zasadne wydaje się twierdzenie, iż terroryzm pozostanie głównym narzędziem walki dżihadystycznej. Niewykluczone jest też zwiększenie intensywności jego wykorzystywania w obliczu rosnącej presji międzynarodowej skierowanej przeciwko Państwu Islamskiemu, co przejawiać się może 
w większej liczbie zamachów terrorystycznych nie tylko na Bliskim Wschodzie, ale i poza nim.

Predykcja rozwoju sytuacji w południowo-wschodniej części Półwyspu Arabskiego prowadzić może do wniosku, iż Al-Kaida na Pótwyspie Arabskim poddana będzie coraz większej presji międzynarodowej wprostproporcjonalnej do sukcesów odnoszonych przez społeczność międzynarodową w walce z Państwem Islamskim (obecnym przecież i w tej części półwyspu). Brak jest wystarczających przesłanek do wskazania, iż dżihadystom z Al-Kaidy na Pótwyspie Arabskim uda się już w 2017 r. zrealizować swe strategiczne zamierzenia, co oznacza dalsze trwanie konfliktu wewnętrznego w Jemenie także w późniejszym okresie. Sytuację komplikować będzie także w dalszym ciagu rebelia szyicka oraz dalsze kontrterrorystyczne zaangażowanie Arabii Saudyjskiej.

Założyć należy także utrzymywanie się konfliktu o niskiej intensywności na terytorium Iraku, Syrii i Turcji, którego stroną będą kurdyjskie grupy terrorystyczne. Ich aktywność będzie ściśle skorelowana z kontrterrorystyczną aktywnością tureckich służb specjalnych czy tureckiego wojska. W obliczu rosnącej z ich strony presji nie można wykluczyć możliwości utrzymania się, a nawet niewielkiego zwiększenia liczby przeprowadzanych przez powyższe grupy akcji terrorystycznych i partyzanckich.

Dopóty, dopóki proces pokojowy nie zostanie reaktywowany i nie przyjmie realnych, instytucjonalnych kształtów (wiążących się choćby z powołaniem do życia państwa palestyńskiego) trudno założyć wycofanie się Palestyńczyków z aktywności asymetrycznej skierowanej przeciwko, jak sami twierdza, okupantowi. Terroryzm (w tym wykorzystywanie terroryzmu indywidualnego i terroryzmu samobójczego) będzie stałym elementem walki narodowowyzwoleńczej. W obliczu braku perspektyw na powyższe rozwiązania, akty terroryzmu palestyńskiego będą trwałym elementem palestyńskiej walki politycznej zarówno w 2017 r., jak też i w okresie późniejszym.

Konkludując, stwierdzić należy, iż terroryzm w dalszym ciagu będzie trwałym, dysfunkcjonalnym elementem kształtującym relacje społeczno-polityczne w tej części świata. Brak politycznych rozwiązań lokalnych sporów i konfliktów oraz ekspansjonistyczne plany dżihadystów w sposób immanentny kształtować będą sytuację na Bliskim Wschodzie.

\section{BIBLIOGRAFIA}

Adnan G. (2016), Islamic State Claims Deadly Car Bombing in Iraq, „The Wall Street Journal”, http://www.wsj.com/articles/islamic-state-claims-deadly-car-bombing-in-iraq-1465320253 (5.01.2017).

Almukhtar S., Watkins D. (2016), The Islamic State Steps Up Terror Attacks in Baghdad, „The New York Times", 3.07, http://www.nytimes.com/interactive/2016/05/18/world/middleeast/baghdad-attacks-isis-map.html (5.01.2017).

At least 9 dead, dozens injured in coordinated Turkey blasts (2016), RT, 10.09.2016, https://www. rt.com/news/355424-mardin-hospital-bomb-blast/ (5.01.2017).

At least 21 dead in Baghdad car bombing (2016a), „Dawn”, 30.04.2016, http://www.dawn.com/ news/1255430/at-least-21-dead-in-baghdad-car-bombing? (5.01.2017). 
At least 16 killed, dozens injured in three bombings in Baghdad (2016c), „Scroll”, 3.10.2016, http:// scroll.in/latest/818191/at-least-16-killed-dozens-injured-in-three-bombings-in-baghdad (5.01.2017).

Baruch U. (2016), Terrorist shot trying to stab at Cave of Machpelah, „Arutz Sheva” 7, 14.02.2016, http://www.israelnationalnews.com/News/News.aspx/208005 (5.01.2017).

Ben-Kimon E., Levy E. (2016), Teenage girl killed, man hurt in Kiryat Arba stabbing attack, „Ynet News”, 30.06.2016, http://www.ynetnews.com/articles/0,7340,L-4822376,00.html (5.01.2017).

Benari E. (2016), Tel Aviv terrorist eliminated one week later, „Arutz Sheva” 7, 8.01.2016, http:// www.israelnationalnews.com/News/News.aspx/206149 (5.01.2017).

Blasts kill at least 17 in Baghdad: police, medics (2016), REUTERS, 27.09.2016, http://www.reuters.com/article/us-mideast-crisis-iraq-blast-idUSKCN11X0PW (5.01.2017).

Bomb attacks damage three Sunni mosques in Iraq (2016), „Al Jazeera”, 4.01.2016, http:// www.aljazeera.com/news/2016/01/sunni-mosques-bombed-town-south-baghdad-160104102900367.html (5.01.2017).

Car bomb hits Dersim, SE Turkey (2016), „K24”, 13.06.2016, http:/www.kurdistan24.net/en/ news/2be01db5-1941-4c43-9116-85a76ea62c3c/Car-bomb-hits-Dersim--SE-Turkey? (5.01.2017).

Car bomb kills four people in Iraq's Salahuddin (2016), „Press TV”, 18.06.2016, http://www.presstv. com/Detail/2016/06/18/471032/Iraq-Salahuddin-Tuz-Khurmatu-Fallujah? (5.01.2017).

Coskun O. (2016), Turkish warplanes strike Iraq after Ankara bombing blamed on Kurdish militants, REUTERS, 14.03.2016, http://www.reuters.com/article/us-turkey-blast-idUSKCNOWF0PP (5.01.2017).

Couzens G. (2016), 'ISIS terrorists slaughter Real Madrid supporters' during Champions League final in bloody new attack, „Mirror”, 29.05.2016, http://www.mirror.co.uk/news/world-news/ isis-terrorists-slaughter-real-madrid-8079016 (5.01.2017).

Damascus hit by multiple bombings (2016), ENCA, 21.02.2016, http://www.enca.com/world/damascus-hit-multiple-bombings (5.01.2017).

Davison J. (2016), Bombs kill nearly 150 in Syrian government-held cities: monitor, REUTERS, 23.05.2016, http://www.reuters.com/article/us-mideast-crisis-syria-latakia-idUSKCNOYEOPB (5.01.2017).

Dolamari M. (2016), Teenage suicide bomber kills six in southern Kirkuk, „Kurdistan 24”, 3.09.2016, http://www.kurdistan24.net/en/news/6a864861-ca29-49b9-a502-5270a579a4d3/Teenagesuicide-bomber-kills-six-in-southern-Kirkuk? (5.01.2017).

Dozens dead in spate of attacks by Isis suicide bombers and gunmen in Iraq (2016), „The Guardian”, 11.01.2016, http://www.theguardian.com/world/2016/jan/11/iraqi-officials-gunmen-stormbaghdad-mall-and-take-hostages (5.01.2017).

Eight suicide bombers target Lebanese Christian village (2016), REUTERS, 27.06.2016, http:// www.reuters.com/article/us-mideast-crisis-lebanon-idUSKCN0ZD09C (5.01.2017).

Gross A. (2016), Policewoman killed, second badly hurt in Jerusalem attack, „The Times of Israel”, 3.02.2016, http://www.timesofisrael.com/2-policewomen-wounded-in-attack-outside-jerusalems-old-city/ (5.01.2017).

Hameed S., Chimaytelli M. (2016), Iraqis want crackdown on 'sleeper cells' after huge Baghdad bomb, REUTERS, 5.07, http://www.reuters.com/article/us-mideast-crisis-iraq-blast-idUSKCN0ZJ017 (5.01.2017).

Hanna J., Basil Y., Noam H. (2016), Saudi Arabia mosque attack: 2 reported killed, CNN, 29.01.2016, http://edition.cnn.com/2016/01/29/middleeast/saudi-arabia-violence/ (5.01.2017). 
Hasson R. (2016), Stabbing in East Jerusalem Leaves Israeli Teen Wounded read, „Haaretz”, 11.08.2016, http://www.haaretz.com/israel-news/1.736375 (styczeń 2017).

Horton M. (2016), AQAP in Southern Yemen: Learning, Adapting and Growing, „Terrorism Monitor", Vol. XIV, Issue 20, 14.10.2016.

Horton M. (2017), Fighting the Long War: The Evolution of al-Qa ida in the Arabian Peninsula, „CTC Sentinel”, Vol. 10, Issue 1, January.

Hume T., Alkhshali H. (2016), ISIS claims responsibility for attack on Baghdad gas plant, CNN News, 15.05.2016, http://us.cnn.com/2016/05/15/middleeast/iraq-violence-isis/index.html? (5.01.2017).

Iraq: Two Car Blast in Shiite City of Samawa, 110 Martyred, Injured; Isis Claims Responsibility (2016), ABNA, 1.05.2016, http://en.abna24.com/service/middle-east-west-asia/archive/2016/05/01/751271/story.html (5.01.2017).

IS Claims Killing 60, Wounding 100 in Suicide Bombing at Funeral in Diyala (2016), SITE Intelligence Group, 29.02.2016, https://news.siteintelgroup.com/Jihadist-News/is-claims-killing60-wounding-100-in-suicide-bombing-at-funeral-in-diyala.html (5.01.2017).

IS Claims Killing Nearly 100 Shi'ites in 5-Man Suicide Raid at Muhammad bin Ali al-Hadi Shrine (2016b), SITE Intelligence Group, 8.07.2016, https://news.siteintelgroup.com/JihadistNews/is-claims-killing-nearly-100-shi-ites-in-5-man-suicide-raid-at-muhammad-bin-ali-alhadi-shrine.html (5.01.2017).

IS Claims Killing Over 65 in al-Iskandariya Suicide Bombing, South of Baghdad (2016), SITE Intelligence Group, 25.03.2016, https://news.siteintelgroup.com/Jihadist-News/is-claims-killingover-65-in-al-iskandariya-suicide-bombing-south-of-baghdad.html (5.01.2017).

IS Claims Killing, Wounding at Least 72 in 8 Suicide Bombings in Iraq and Syria (2016), SITE Intelligence Group, 4.04.2016, https://news.siteintelgroup.com/Jihadist-News/is-claims-killingwounding-at-least-72-in-8-suicide-bombings-in-iraq-and-syria.html (5.01.2017).

ISIS blows up power transmission towers in eastern Tikrit (2016), „Iraqi News”, 22.06.2016, http:// www.iraqinews.com/iraq-war/isis-blows-up-power-transmission-towers-eastern-tikrit/ (5.01.2017).

Islamic State Claims Suicide Bombing at Iraqi Wedding (2016), „The New York Times”, 29.08.2016, http://www.nytimes.com/reuters/2016/08/29/world/middleeast/29reuters-mideast-crisisiraq-blast.html (5.01.2017).

Istanbul bombing: Kurdish TAK claims responsibility (2016), „Al Jazeera”, 10.06.2016, http:// www.aljazeera.com/news/2016/06/istanbul-bombing-kurdish-tak-claims-responsibilility-160610074254229.html (5.01.2017).

Istanbul terror attack death toll increases to 44 (2016), „Daily Sabah”, 10.12.2016, https://www. dailysabah.com/war-on-terror/2016/12/12/istanbul-terror-attack-death-toll-increases-to-44 (5.01.2017).

Kubovich Y. (2016), Four Killed, Six Wounded in Shooting Attack at Tel Aviv Shopping Center, „Haaretz”, 8.06.2016, http://www.haaretz.com/israel-news/1.723941 (5.01.2017).

Lister C. (2016), The Dawn of Mass Jihad: Success in Syria Fuels al-Qa ida’s Evolution, „CTC Sentinel", Vol. 9, Issue 9, September.

Man Stabbed in Jerusalem (2016), „The Jewish Press”, 3.01.2016, http://www.jewishpress.com/ news/breaking-news/woman-stabbed-in-jerusalem/2016/01/03/ (styczeń 2017).

Multiple Bomb Blasts Kill 12 in, around Iraq's Baghdad, ISIS Responsible? (2016), ALALAM, 8.05.2016, http://en.alalam.ir/news/1816170? (styczeń 2017).

Ozcan N. A. (2016), Turkey's Dance with the Islamic State, „Terrorism Monitor”, Vol. XIV, Issue 2, January 22. 
Al-Qaeda's Syrian branch kidnaps activists in north (2016), Panarmenian.net, 11.01.2016, http:// www.panarmenian.net/eng/news/203462/AlQaedas_Syrian_branch_kidnap_activists_in_ north (5.01.2017).

Palestinian Attacker Stabs Israeli Woman in West Bank (2016), „The New York Times”, 18.01.2016, http://www.nytimes.com/aponline/2016/01/18/world/middleeast/ap-ml-israel-palestinians. html (5.01.2017).

Pothecary J. (2016), Why Al-Nusra's 'Break' With Al-Qaeda Poses a Problem for the West, „Terrorism Monitor", Vol. XIV, Issue 21, October 28.

al-Qalisi M. (2016), Car bomb targets Houthis in Yemen capital, „The National”, 23.07.2016, http://www.thenational.ae/world/middle-east/car-bomb-targets-houthis-in-yemen-capital? (5.01.2017).

Rowley L. (2016), Gunmen Attack Baghdad Mall, Killing at Least 10 - Here's the Latest on Hostage Situation, „News.Mic”, 11.01.2016, http://mic.com/articles/132297/gunmen-attack-baghdad-mall-killing-at-least-10-here-s-the-latest-on-hostage-situation (5.01.2017).

Schram J., Steinbuch Y. (2016), American fatally stabbed in Israel ahead of Biden visit, „New York Post”, 8.03.2016, http://nypost.com/2016/03/08/at-least-10-israelis-stabbed-in-tel-aviv/ (5.01.2017).

Schmid A. P. (2011), The Routledge handbook of terrorism research, London-New York.

Schmid Alex P., Jongman A. J. (2005), Political Terrorism. A New Guide to Actors, Authors, Concepts, Data Bases, Theories, \& Literature, New Brunswick-London.

Serbest E. (2016), Turkish guide prevented more casualties in Istanbul attack, „Hurriyet Daily News”, 14.01.2016, http://www.hurriyetdailynews.com/turkish-guide-prevented-more-casualties-inistanbul-attack.aspx?PageID=238\&NID=93851\&NewsCatID=341 (5.01.2017).

Shapiro J. (2016), A Predictable Failure: The Political Economy of the Decline of the Islamic State, „CTC Sentinel”, Vol. 9, Issue 9, September.

Six killed in multiple bomb blasts in Baghdad (2016), „Al-Bawaba News”, 2.02.2016, http://www. albawaba.com/news/six-killed-multiple-bomb-blasts-baghdad-800866 (5.01.2017).

Six Dead in Yemen Market Bombing (2016), „Outlook”, 6.05.2016, http://www.outlookindia.com/ newswire/story/six-dead-in-yemen-market-bombing/939236? (5.01.2017).

Suicide bomber kills at least 40 in Mukalla (2016), „The National”, 15.05.2016, http://www.thenational.ae/world/middle-east/suicide-bomber-kills-at-least-40-in-mukalla (5.01.2017).

Suicide Bomber Targets Shiites in Iraqi Capital, Kills 7 (2016), „The New York Times”, 25.09.2016, http://www.nytimes.com/aponline/2016/09/25/world/middleeast/ap-ml-iraq.html?ref=world (5.01.2017).

al-Tamimi A. (2016), Al-Qa ida's Uncoupling: Jabhat al-Nusra's Rebranding as Jabhat Fateh alSham, „CTC Sentinel”, Vol. 9, Issue 8.

Three Terrorist explosions hit al-Sayda Zainab, Damascus, 60 martyred (2016b), ABNA, 31.01.2016, http://en.abna24.com/service/middle-east-west-asia/archive/2016/01/31/732718/story.html? (5.01.2017).

Turkish opposition leader escapes assassination attempt (2016), „Al Jazeera”, 25.09.2016, http:// www.aljazeera.com/news/2016/08/turkish-opposition-leader-escapes-assassination-attempt-160825131927382.html (5.01.2017).

Two suicide bombers kill 15 at Shi'ite mosque in Baghdad (2016), REUTERS, 26.02.2016, http:// www.reuters.com/article/us-mideast-crisis-iraq-blast-idUSKCNOVY2AH (5.01.2017).

Weinberg L., Pedahzur A., Hirsch-Hoefler S. (2004), The Challenges of Conceptualizing Terrorism, „Terrorism and Political Violence”, Vol. 16, No. 4.

Wejkszner A. (2016), Państwo Islamskie. Narodziny nowego kalifatu?, Warszawa. 
Wejkszner A. (2017), Globalna sieć Al-Kaidy. Nowe państwo islamskie?, Warszawa.

Wootliff R. (2016), Woman, 23, dies of wounds after Beit Horon stabbing, „The Times of Israel”, 26.01.2016, http://www.timesofisrael.com/woman-24-dies-of-wounds-after-stabbing-in-settlement-market/ (5.01.2017).

Yeginsu C. (2016a), Bombing at Wedding in Turkey Kills More Than 50, „The New York Times”, 21.08.2016, http://www.nytimes.com/2016/08/22/world/europe/turkey-wedding-attack-isisblamed.html (5.01.2017).

Yeginsu C. (2016b), Explosion in Ankara Kills at Least 34, Turkish Officials Say, „The New York Times", 13.03.2016, https://www.nytimes.com/2016/03/14/world/middleeast/explosion-ankara-turkey.html (styczeń 2017).

Yegnisu V., Callimachi R. (2016), Turkey Says Airport Bombers Were From Kyrgyzstan, Russia and Uzbekistan, „The New York Times”, 30.06.2016, http://www.nytimes.com/2016/07/01/ world/europe/istanbul-airport-attack-turkey.html (5.01.2017).

Yemen crisis: Aden governor survives 'IS bomb attack' (2016), „BBC News”, 5.01.2016, http://www. bbc.com/news/world-middle-east-35236572 (5.01.2017).

Zeyrek D. (2016), Istanbul suicide bomber 'known but not tracked', „Hurriyet Daily News”, 23.03.2016, http://www.hurriyetdailynews.com/istanbul-suicide-bomber-known-but-nottracked.aspx (5.01.2017).

Zitun Y. (2016), Shin Bet detains suspects in search for terrorist who murdered Israeli woman, „Ynet News”, 18.01.2016, http://www.ynetnews.com/articles/0,7340,L-4754361,00.html (5.01.2017).

\title{
STRESZCZENIE
}

Przedmiotem rozważań w niniejszym artykule jest problematyka ewolucji zagrożenia terrorystycznego na Bliskim Wschodzie w $2016 \mathrm{r}$. W tym celu analizie poddano, po pierwsze, istotę i determinanty współczesnego zagrożenia terrorystycznego. Wskazano także najważniejsze podmioty terrorystyczne aktywne na Bliskim Wschodzie. Po drugie - przedstawiono chronologię i najważniejsze trendy w ramach aktywności terrorystycznej w tym regionie. I wreszcie, po trzecie, skupiono się na predykcji najważniejszych trendów rozwoju powyższego fenomenu w 2017 r. i kolejnych latach.

Słowa kluczowe: Bliski Wschód, terroryzm, Al-Kaida, Państwo Islamskie, kalifat, Irak, Turcja, Syria, Jemen

\section{THE EVOLUTION OF THE TERRORISM THREAT IN THE MIDDLE EAST IN 2016}

\begin{abstract}
The main aim of this article is to present an evolution of the terrorism threat in the Middle East in 2016. For this purpose, firstly, the essence and determinants of the contemporary terrorism threat have been analyzed. Some main Middle East terrorist organizations, actively operating in this area, have also been indicated. Secondly, the chronology and the most important terrorism trends in the region have been presented. And last but not least some predictive scenarios regarding the development of above phenomenon in 2017 and beyond have been pointed out.
\end{abstract}

Keywords: Middle East, terrorism, Al-Qa'ida, Islamic State, caliphate, Iraq, Turkey, Syria, Yemen 
